\title{
Экосистемы градостроительства в постсоциалистическом контексте. Часть 1. Бывшие советские республики: между "архитектурой" и "планировкой"
}

\author{
Н.Н.Жеблиенок, Лаборатория градопланирования, Санкт-Петербург
}

Статья посвящена процессам формирования профессиональной культуры и системы ценностей в области градостроительства в постсоциалистических странах. Исследование сосредоточено на мотивах и инструментах, посредством которых развиваются национальные институты профессионального градостроительства. Отношение к социалистическому прошлому предопределяет степень влияния общеевропейских моделей на развитие всей отрасли: нейтральные оценки (Словакия, Сербия) способствуют поступательному линейному развитию систем образования и деятельности. Критическое отношение к социалистическому этапу (Эстония, Польша, Литва, Латвия) обуславливает повышенное внимание к компенсационным действиям: усилению практики соучастия, развитию социальной составляющей в исследованиях, постепенный переход от архитектурной модели профессионального образования к внеархитектурным. Позитивное отношение к социалистической парадигме (Молдова, Белоруссия, Армения) служит причиной усиления позиций архитектурной модели в профессиональном образовании градостроителей, поддерживает сложившуюся систему профессиональных ценностей, основанную на творческом подходе к градостроительной деятельности. Посредством сравнительного анализа образовательных программ, профессиональных стандартов, законодательных инициатив, должностных классификаторов выделено четыре «модели специалиста», характерные для различных национальных институтов профессионального градостроительства («архитектор-планировщик», «градостроитель», «градостроитель со специализацией» или «профессионал с градостроительной специализацией»), описаны соответствующие этим моделям сценарии развития градостроительной отрасли. Выявлен ряд тенденций, свидетельствующих, что профессионально-отраслевая трактовка градостроительства сменяется эко-системным подходом, особое значение приобретает культурная составляющая современного градостроительства; вызовы, которые стоят перед национальными институтами всё меньше касаются их роста и соответствия условным «мировым стандартам» и всё более - трансформациям и гибкости.

Ключевые слова: профессия «градостроитель», постсоциалистическое градостроительство, высшее градостроительное образование, институт градостроительства.

\section{Ecosystems of Urban Planning in a Post-Socialist Context. Part 1. Former Soviet Republics: Between "Architecture" and "Planning"}

N.N.Zheblienok, Urban Planning Laboratory, St. Petersburg The article is devoted to the processes of formation of professional culture and system of values in the field of urban planning in post-socialist countries. The study focuses on the motives and tools through which the national institutions of professional urban planning are developed. The attitude to the socialist past predetermines the degree of influence of common European models on the development of the whole branch: neutral evaluations (Slovakia, Serbia) contribute to the progressive linear development of educational systems and activities. Critical attitude to the socialist stage (Estonia, Poland, Lithuania, Latvia) determines the increased attention to compensatory actions: strengthening of coparticipation practice, development of social component in research, gradual transition from an architectural model of professional education to extra-architectural ones. A positive attitude to the socialist paradigm (Moldova, Belarus, Armenia) is the reason for architectural model strengthening in the professional education of urban planners, supports the established system of professional values based on the creative approach to urban planning. With the help of the comparative analysis of educational programs, professional standards, legislative initiatives, job classifiers the four "models of specialist" characteristics for different national institutions of professional urban planning are singled out ("architect-planner", "urban planner", "urban planner with a specialization" or "professional with urban planning specialization"), the scenarios of the urban planning branch development corresponding to these models are described. The author has revealed several tendencies, testifying that the professional and branch interpretation of urban development is replaced by the ecosystem approach, the cultural component of modern urban development acquires a special meaning, the challenges faced by the national institutions areless andless related to their growth and compliance with the conventional "world standards" and more and more to their transformation and flexibility.

Keywords: profession of "urban planner", post-socialist urban planning, higher urban planning education, institute of urban planning. 
Влияние социалистических идей и их интерпретаций на страны Восточной Европы в XX веке трудно переоценить. Пик этого влияния пришелся на крайне существенные с точки зрения наращивания темпов урбанизации десятилетия. Градостроительство этих стран (как институт, отрасль, культурное явление) получило некоторую общность политического контекста. Это означало, что основы их национальных институтов профессионального градостроительства, уже сформированные в начале XX века, после 1920-1930-х годов оказались невостребованными. Локальную самобытность сменила относительно универсальная, в большинстве своём русифицированная, культура профессионального архитектурно-планировочного мышления. В конце 1980-х годов эта ситуация изменилась. Страны (объединяемые абстрактным «постсоциалистическим» статусом) столкнулись с проблемами кадрового, правового, методического дефицита в области градостроительства.

Фактически - это всё, что мы знаем о состоянии их градостроительства. Что из общего социалистического наследия стало основой для новых форм градостроительства ${ }^{1}$, развиваемых на постсоциалистическом пространстве? Какие стратегии были выбраны ими² для преодоления кризиса? Эти вопросы продиктованы не интересом к истории, по крайней мере, далеко не только им. В современном мире представляется недостаточным оценивать уровень развития градостроительства исключительно с позиций его пространственно-материальных достижений, то есть исследуя проектную практику или оценивая среду городов. Там, где мы хотим сформировать понимание о градостроительстве, а не только о городах 3 , территориальные объекты должны стать только одним из компонентов профессионального дискурса; существенную же его часть должны занимать вопросы профессионального мышления, институционализации отрасли [2; 3]. Передовые зарубежные исследования сосредоточены на том, кто и как формулирует стратегические цели, разрабатывает решения, устанавливает ограничения, влияет на их реализацию; не менее важную роль играют методы, инструменты и системы, регулирующие возникшие при этом связи. Подлинные очертания пространств и сред нашего жизнеобитания сегодня можно увидеть только через призму сопровождающих и породивших их процессов.

Цель исследования - способствовать повышению осведомленности о системах профессиональных отношений и ценностей, а также обстоятельствах развития градостроительства в соседних с РФ государствах (Польша, Сербия, Венгрия, Республика Беларусь, Республика Молдова, Республика Армения, Эстонская Республика, Литовская Республика, Латвийская Республика) ${ }^{4}$. Методика исследования опиралась результаты ранее выполненных НИР 5 . Так, при изучении типологического разнообразия систем градостроительного образования разных стран мира [5-6] эффективным оказалось применение системы маркеров ${ }^{6}$, которые суммарно, как предполагается, позволяют оценить актуальное состояние трёх структурных компонентов современного градостроительства: систему градостроительного знания (СГЗ), систему градостроительной деятельности (СГД) и систему градостроительного образования (СГО) (рис. 1).

Содержательной проблемой исследования стала терминологическая неоднозначность понятий «градостроительство», «урбанистика», их вариантов перевода в рассматриваемых странах. Были приняты допущения: понятия «градостроительство», «urban planning» и «city planning» рассматриваются с позиций данного исследования как синонимичные; для Прибалтийских стран термин «linnaplaneerimine» был переведён как «градостроительство», «plānošana» - «планировка», а термин «urbanistika» как «урбанистика»; в Республике Молдова используется термин «градостроение», но он переводится на английский как «urban planning» и может рассматриваться как аналог термина «градостроительство».

Многие учёные отмечают, что феномен постсоциалистического постепенно теряет свою актуальность [7; 8]. Более тридцати лет развитие стран, причисляемых к этому перечню, происходит в известной степени независимо. 0днако в отношении исследуемых отраслей градостроительства обсуждение степени их родства всё ещё уместно; причины этому - инертность процессов городского планирования [2; 8], экономические предпосылки [3], консервативность образовательных структур [8].

${ }^{1}$ Нет сомнений, что градостроительство в высшей степени контекстуально. То есть глубоко обусловлено политическим, экономическим, культурным контекстом. Смена политического курса с переходом на рыночную экономику и многопартийное государственное управление потребовала перемен в организации градостроительных процессов, обустройстве системы планирования и выстраивании связей внутри неё. А также обусловило появление множества новых дисциплин и видов профессиональных задач.

${ }^{2}$ Сменив социалистические ориентиры на демократические, рассматриваемые страны влились в общемировой градостроительный дискурс. Сегодня в нём главенствует концепция совместных коммуникативных процессов в ходе решения пространственно-территориальных задач. Регионально-национальные вариации прочтения этого курса и составили содержание настоящего исследования.

${ }^{3}$ В исследовании [1] метко подмечено: «удивительно, но при огромном количестве описаний городов... самому анализу истории формирования дисциплины и проблемам, связанным с расширением её методического арсенала, уделяется явно недостаточно внимания».

${ }^{4}$ Также были исследованы институты градостроительства в Республике Казахстан, Киргизской Республике, Болгарии, Чешской республике, Российской Федерации (https://www.gradotomia.com/post/postsoviet-urban-plamnning-cheklist). Данные по этим странам подробно в статье не приводятся.

${ }^{5}$ В 2017-2020 годы автор (под руководством акад. Ю.П. Бочарова) проводила НИР «Формирование научных основ междисциплинарного взаимодействия в градостроительстве», тема № 5.1.6/4.2.13. и НИР 4.2.4 «Научные основы повышения профессиональной квалификации в градостроительстве» [4-6].

${ }^{6}$ Сравнительный анализ образовательных программ, выпускных работ, их ценностных установок; стандартов, регламентирующих градостроительную деятельность; контент-анализ публикаций; систематизация международных отчетов. Были использованы данные из открытых источников. 
ЭТАПЫ И МАРКЕРЫ РАЗВИТИЯ ИНСТИТУТА ГРААОСТРОИТЕАЬСТВА

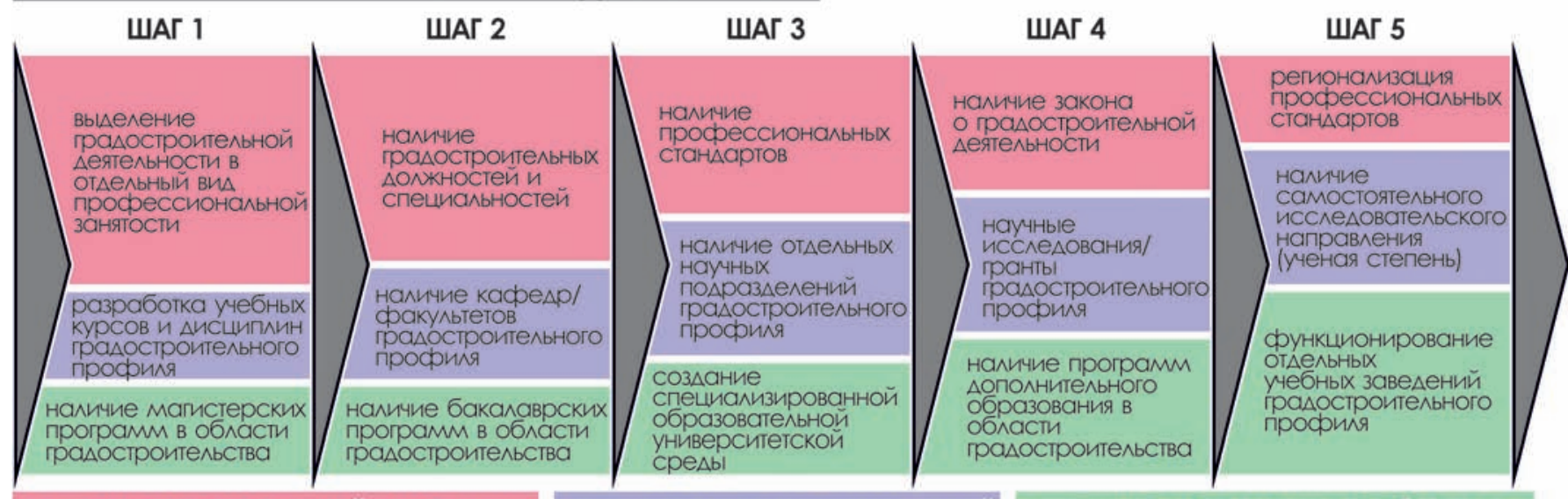

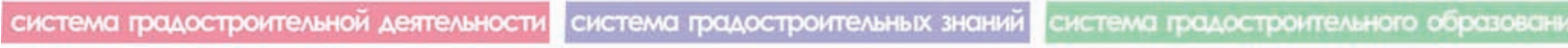

\section{УРОВЕНЬ РАЗВИТИЯ НАЩИОНАИЬНЫХ ИНСТИТУТОВ ГРААОСТРОИТЕАЬСТВА}

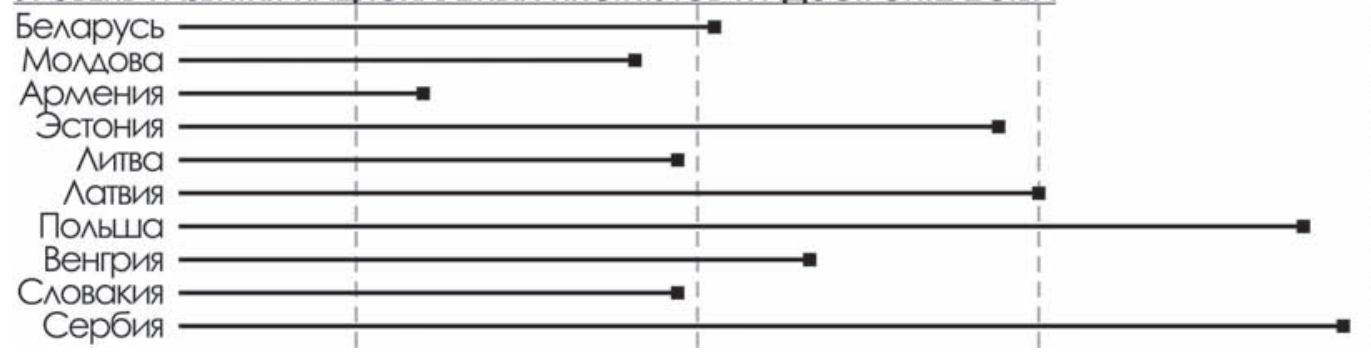

Рис. 1. Концепция пошагового развёртывания института профессионального градостроительства. Автор концепции Н.Н. Жеблиенок

\section{АНГАО-САКСОНСКАЯ ШКОАА ГРААОСТРОИТЕАЬСТВА}

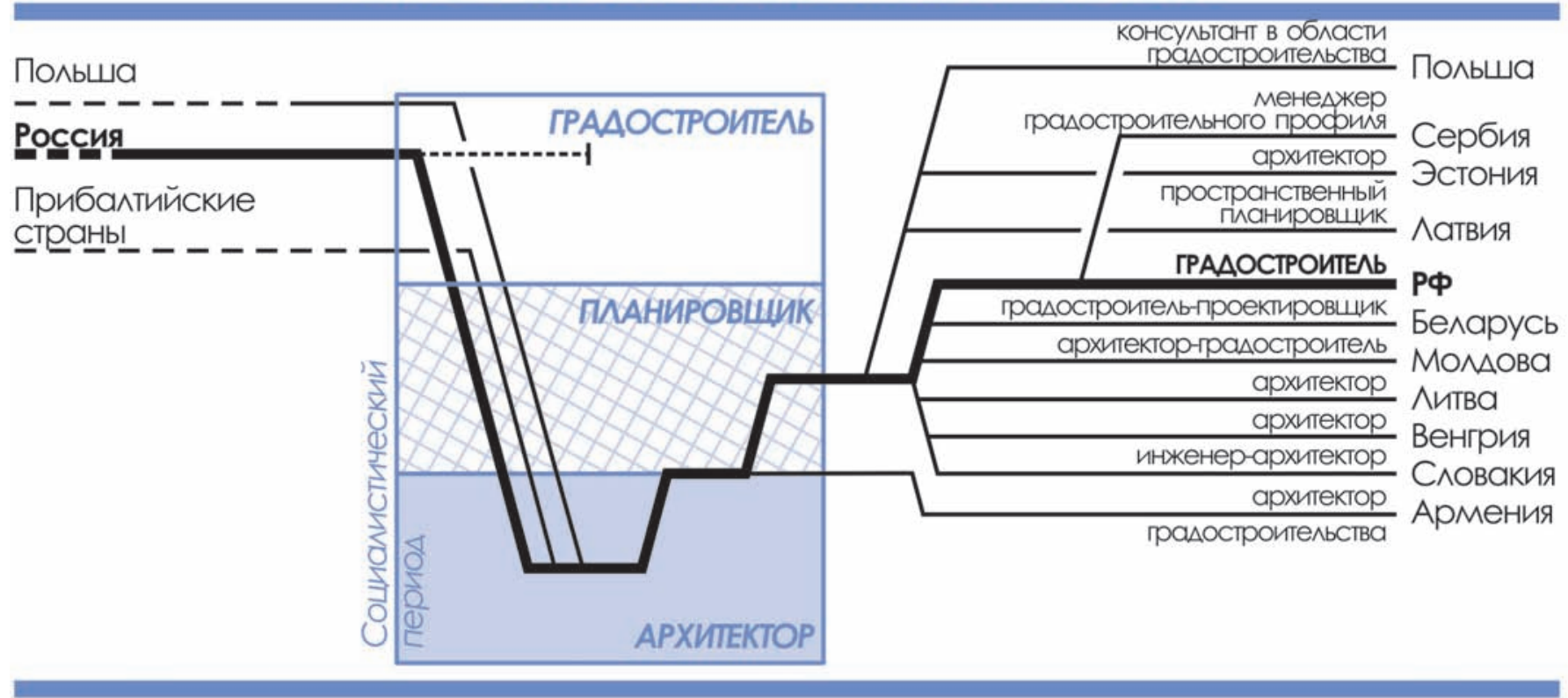

МАТИНСКАЯ ШКОЛА ГРААОСТРОИТЕАЬСТВА

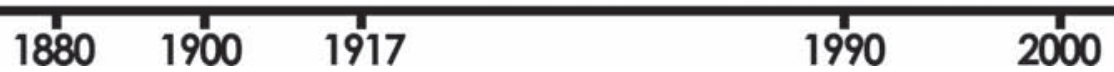

Рис. 2. Графо-аналитическое обобщение основных этапов формирования институтов профессионального градостроительства в постсоциалистических странах. ХХ-ХХІ века. Автор схемы Н.Н. Жеблиенок 
Графически сопоставление сценариев развития институтов профессионального градостроительства на постсоциалистическом пространстве приводит нас к выделению трёх крупных этапов: самобытного формирования в начале XX века, затем совместного социалистически-ориентированного развития в едином русле. И далее - в течение последних тридцати лет - трансформация имеющегося наследия посредством корректировки модели специалиста, представляющего собой центральное действующее лицо отрасли (рис. 2).

«Исходный код» социалистически-ориентированной системы профессионального градостроительного образования основывался на квалификации «архитектор» [9]; её дополнял «инженер по специальности городское строительство» профессии «градостроитель» не существовало $0^{8}$. Доступ к градостроительному образованию подразумевал прохождение творческих испытаний, композиционные и художественные навыки сохраняли важность в профессиональной деятельности ${ }^{9}$. Инженерно-экономические и технические факультеты параллельно готовили инженеров, транспортников и экономгеографов; специальности развивались без связи между собой [9]; подготовка велась для внутреннего рынка труда максимально унифицировано (в условиях распределения выпускников после окончания обучения регионализация образовательных сценариев была лишена смысла).

В социалистических странах градостроительство не было оформлено как самостоятельная специализация; в отсутствие профессиональных стандартов структура требуемых навыков, состав учебных планов были предметом дискуссий и экспериментов. Такое положение вещей характерно для институтов профессионального градостроительства во всём мире до настоящего времени [8;11]. Дискуссии о принципиальной возможности создания универсальной доктрины планирования жёстко критикуются сторонниками необходимости адаптировать работу градостроительных институтов к местным условиям и обычаям [11]. С формально-обобщённой точки зрения характеристики постсоциалистических институтов градостроительства представлены в таблице 1.

\section{Страны, ранее входившие в состав СССР}

Республика Беларусь. В системе градостроительного образования в Республике Беларусь (далее - РБ) главенствует «архитектурная модель». Вступительные испытания включа- ют творческий экзамен; ряд учебных заведений (например, Брестский государственный технический университет - БГТУ) сохранил традицию отбора абитуриентов с применением экзамена по черчению. Подготовка кадров ориентирована строго на внутренний рынок. Некоторый внешний консерватизм может компенсироваться установками на создание коммуникационной среды в высших учебных заведениях: на инженерно-строительном факультете Полоцкого государственного университета (ПГУ), так же как и в БГТУ, совместно обучаются инженеры-строители, дизайнеры и архитекторы. ПГУ выдвигает ряд инновационных актуальных идей в сфере образования («индивидуальные траектории развития», soft skills и т.д.), свидетельствующих о методических усовершенствованиях процесса распространения градостроительных знаний. Интересно выглядят урбанистические инициативы ${ }^{10}$, направленные на привлечение историков, социологов, психологов, экологов к обсуждению градостроительных проблем.

С формальной точки зрения ситуация выглядит неоднозначно: в Общегосударственном классификаторе РБ ${ }^{11}$ градостроительство технически-ориентировано: «градостроители» находятся в одной группе с «архитекторами, проектировщиками, топографами и дизайнерами», разделяя общую с «проектировщиками транспортныхузлов и другими специалистами-профессионалами, занятыми диспетчеризацией транспортных потоков» подгруппу. Они «разрабатывают и реализовывают планы и политику контролируемого использования земель... и транспортных систем... проводят исследования и консультируют по вопросам... влияющим на землепользование и транспортные потоки» ${ }^{12}$. Несмотря на то, что «консультирование» формально входят в обязанности «градостроителя-проектировщика», для профессионального сообщества градостроительство всё ещё безраздельно принадлежит архитектуре. В приоритете отрасли «создание многофункциональной городской среды... развитие сети общественных пространств, где люди могут общаться, обмениваться идеями... создание «умных» городов, насыщенных новейшими технологиями... создание красивых городов с ... выразительной архитектурой» [14].

Республика Молдова. Республика Молдова (далее РМ) также оценивает социалистический опыт развития градостроительства как положительный, «архитекторы и градостроители всех поколений умели поставить на алтарь искусства всё своё умение» ${ }^{13}$. В Классификаторе

\footnotetext{
${ }^{7}$ Их выпуском занимались кафедры «ГСХ» (городского строительства и хозяйства).

${ }^{8}$ Исключения редки: так, в Болгарии и Чехословакии велась подготовка специалистов по направлению «физическое планирование и городской дизайн» (physical planners and urban designers), но на архитектурных факультетах [8; 9].

${ }^{9}$ Согласно [10] имели место «архитектурная» (построенная на приоритете творческих компетенций) и «внеархитектурная» (преимущественно инженерные навыки) модели градостроительного образования; понятие «градостроитель» негласно увязывалось с принадлежностью к «архитектурной» модели.

${ }^{10}$ К таким инициативам могут быть отнесены “Novopolotsk is new again. Version 2.0”, «Polotsk. Let's build bridges», «Novogrudok. Save the future» [13], экспериментальные «Планы городского зелёного развития» [13] создают новые - вне традиционного профессионального контекста - диалоговые платформы для стратегического планирования будущего белорусских городов.

${ }^{11}$ Общегосударственный классификатор Республики Беларусь (http://www.mintrud.gov.by/system/extensions/spaw/uploads/files/0KPB-1.pdf).

12 Там же.

13 Поздравление Президента Союза Архитекторов Р. Молдова Юрия Повара (http://www.uarm.md/novosti/327-pozdravlenie-prezidenta-soyuzaarkhitektorov-r-moldova-yuriya-povara.html).
} 
Таблица 1. 0бщие характеристики состояния института профессии градостроителя

\begin{tabular}{|c|c|c|c|c|c|c|}
\hline \multirow[b]{2}{*}{ 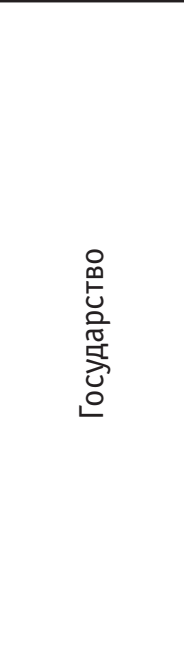 } & \multirow[b]{2}{*}{ 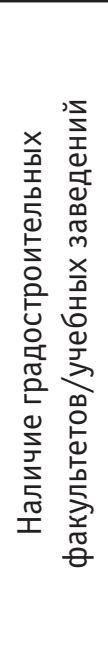 } & \multicolumn{2}{|c|}{ Наименование образовательных программ ${ }^{14}$} & \multirow[b]{2}{*}{ 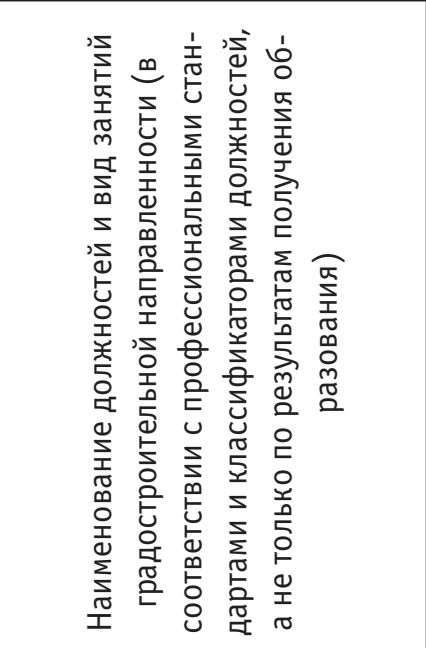 } & \multicolumn{2}{|c|}{$\begin{array}{c}\text { Модель } \\
\text { образования }\end{array}$} \\
\hline & & магистерских & бакалаврских & & 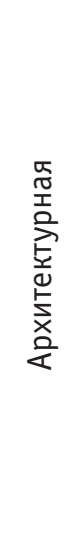 & 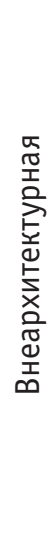 \\
\hline Россия ${ }^{15}$ & + & $\begin{array}{c}\text { Градостроительство, } \\
\text { районная плани- } \\
\text { ровка, планировка } \\
\text { сельских населённых } \\
\text { пунктов }\end{array}$ & $\begin{array}{l}\text { Градостроительство, } \\
\text { градостроительное } \\
\text { проектирование }\end{array}$ & Градостроитель & + & + \\
\hline Молдова & + & $\begin{array}{c}\text { Градостроение и } \\
\text { обустройство терри- } \\
\text { тории }\end{array}$ & Архитектура & Архитектор-градостроитель & + & - \\
\hline Армения & - & Архитектура & Архитектура & $\begin{array}{c}\text { Архитектор градостроитель- } \\
\text { ства }\end{array}$ & + & - \\
\hline Эстония & - & $\begin{array}{c}\text { Архитектура и город- } \\
\text { ской дизайн; Управ- } \\
\text { ление городскими } \\
\text { и индустриальными } \\
\text { ландшафтами }\end{array}$ & Архитектура & Архитектор & + & + \\
\hline Латвия & - & $\begin{array}{c}\text { Ландшафтная архи- } \\
\text { тектура и планиров- } \\
\text { ка; Архитектура }\end{array}$ & Архитектура & $\begin{array}{c}\text { Градостроитель и планиров- } \\
\text { щик дорожного движения }\end{array}$ & + & - \\
\hline Литва & - & Архитектура & Архитектура & Архитектор & + & - \\
\hline Белоруссия & - & Архитектура & Архитектура & $\begin{array}{c}\text { Градостроитель-проекти- } \\
\text { ровщик }\end{array}$ & + & - \\
\hline Польша & + & $\begin{array}{l}\text { Архитектура, про- } \\
\text { филь «Инфраструк- } \\
\text { турный урбанизм» }\end{array}$ & $\begin{array}{c}\text { Устойчивые техноло- } \\
\text { гии; Архитектура }\end{array}$ & $\begin{array}{c}\text { Архитектор; Инженер; } \\
\text { Консультант в области ур- } \\
\text { банизма }\end{array}$ & + & + \\
\hline Сербия & + & Архитектура & Архитектура & $\begin{array}{c}\text { Архитектор; Архитектор-ме- } \\
\text { неджер градостроительного } \\
\text { профиля }\end{array}$ & + & + \\
\hline Венгрия & & Архитектура & Архитектура & Архитектор & + & - \\
\hline Словакия & & $\begin{array}{c}\text { Городской дизайн; } \\
\text { Архитектура }\end{array}$ & $\begin{array}{c}\text { Архитектура и город- } \\
\text { ской дизайн }\end{array}$ & $\begin{array}{c}\text { Инженер-архитектор; } \\
\text { Инженер }\end{array}$ & + & + \\
\hline
\end{tabular}

14 Приведены некоторые наименования программ, наиболее рельефно иллюстрирующие развитие системы профессионального образования.

${ }^{15}$ Данные приведены для сравнения, отечественный опыт подробно в статье не анализируется. 
занятий ${ }^{16}$ [17] градостроительство входит в состав группы «проектировщики в градостроительстве и проектировщики транспортных узлов»; в этой группе «архитектор градостроительства», «инженер садово-паркового хозяйства», «инженер по проектно-сметной работе (в транспортном и городском строительстве)» и «урбанист» (!). Несмотря на это разнообразие, в документах встречаются только «планировщики и архитекторы» ${ }^{17}$.

В Техническом университете Молдовы на факультете «Градостроительство и архитектура» обучают по специальностям «Архитектура» и «Градостроение и обустройство территории» (по направлению подготовки «Архитектура и конструкции»). Архетип «архитектора-планировщика» выступает главным лицом официального градостроительства (архитектор обладает кредитом доверия на любые инфраструктурные, планировочные, средовые решения: «архитекторы выступают за пересмотр всей уличной системы» и даже «архитекторы предлагают переместить Северный автовокзал ...в административном порядке запретить доступ личного транспорта» [15]). Тогда как у общественных инициатив появляются иные независимые представители, симпатизирующие зарубежным урбанистическим концепциям [16]. Контент-анализ по теме «молдавское градостроительство» позволяет выделить только англоязычные тексты ${ }^{18}$ румынских, венгерских и иных европейских научных школ; они оценивают уровень развития градостроительства в РМ (подразумевая обеспеченность градостроительной документацией, её согласованность между собой) как крайне неудовлетворительный ${ }^{19}$.

Республика Армения. В Классификаторе профессий ${ }^{20}$ Республики Армения (далее - РА) должность «архитекторградостроитель» относится к группе архитектурных специальностей. Сохранена логика развития, сформированная в советское время. «Градостроительство» рассматривается как дисциплина архитектурного цикла. Учебная среда организована по принципу учебных заведений тридцатилетней давности: так, Национальный университет архитектуры и строительства Армении ${ }^{21}$ - специализированное обособленное учебное заведение, схожее по структуре с советскими архитектурностроительными вузами. Учебное заведение имеет тесные связи с «высшими национальными архитектурными школами... Лиона... Флоренции» - то есть со школами, традиционно поддерживающими архитектурную модель в подготовке градостроителей; при этом «диплом, выдаваемый выпускникам архитектурного факультета, официально признаётся эквивалентом французского диплома» [17]. Параллельно развивается среднее специальное образование 22 (в области кадастра, инженерного и строительного дела). На фоне призывов к актуализации градостроительной политики ${ }^{23}$ в РА налаживаются связи с градостроительными учебными заведениями США ${ }^{24}$, которые инициируют открытие исследовательских пост-дипломных программ в области городского управления.

Эстонская Республика. Градостроительное образование также сохраняет «подчинённое положение» внутри системы архитектурного образования. В реестре профессий обязанности градостроителя условно «распределены» между инженером широкого профиля, архитектором и строителем. В Эстонской академии художеств (Таллинн) ведётся магистерская программа «Архитектура и градостроительство ${ }^{25} »$. Несмотря на её очевидную про-художественную ориентацию, в программе отражены современные тенденции расширения архитектуры до границ областей пространственного планирования и исследований специфических закономерностей жизненных процессов человека. «Архитектор должен придать современным технологиям понятную для человека материальную форму... в соответствии с культурными ожиданиями... Архитектура предназначена для постоянного внедрения инноваций... и предложения различных взглядов на будущее» ${ }^{26}$ [21]. Градостроительство остаётся в Эстонии частью архитектуры, но границы «архитектуры» сегодня трактуются столь глубоко и сложно, что в конечном итоге и содержание градостроительства оказывается довольно близко передовому мировому опыту.

Для Эстонии характерны тенденции переосмысления роли территориального планирования, проектирования городской среды и связанной с этим деятельности в виде самостоятель-

\footnotetext{
${ }^{16}$ Классификатор занятий Республики Молдова от 03.03.2014 (https://www.angajat.md/files/Clasificatorul\%20ocupatiilor\%20\%28ru\%29.pdf).

${ }_{17}^{17}$ Например, в законе от 26.06.2016 nо. 10 «0 продвижении использования энергии из возобновляемых источников» (http://extwprlegs1.fao.org/docs/ pdf/mol178508.pdf) в числе тех, кого необходимо информировать о перспективах возобновляемых источников энергии, указаны только эти специальности.

${ }^{18}$ Имеется в виду, что собственно молдавских градостроительных исследований фактически не выявлено.

${ }^{19}$ «Local environmental strategic planning processes and practices (LESPPP) in Moldova» (https://www.researchgate.net/publication/276204828_LOCAL_ ENVIRONMENTAL_STRATEGIC_PLANNING_PROCESSES_AND_PRACTICES_LESPPP_IN_MOLDOVA).

${ }^{20}$ Классификация профессий, специальностей и должностей работников PA (http://www.arlis.am/Annexes/4/GT30.1_13page862-1221.doc).

${ }^{21}$ См. подробнее https://free-apply.com/en/university/1005100019.

${ }^{22}$ См. программы профессионального колледжа «Нуака» (https://www.spyur.am/ru/companies/professional-education-college-of-national-universityof-architecture-and-construction-of-armenia-nuaca-foundation/80758).

${ }^{23}$ Призыв «Урбанистические процессы в Армении: от городского планирования к градостроительству» (в оригинале - On Urbanization in Armenia: From "City-Building" to Urban Planning) иллюстрирует отношение молодёжи к потенциалу армянского градостроительства (см. https://www.evnreport.com/rawunfiltered/on-urbanization-in-armenia-from-city-building-to-urban-planning).

${ }^{24} \mathrm{CM.} \mathrm{подробнее} \mathrm{(https://priceschool.usc.edu/price-zerunyan-endeavor-to-establish-phd-policy-management-program-in-armenia/).}$

${ }^{25}$ В оригинале это «arhitektuur jalinnaplaneerimine» и ближе по смыслу к термину «планировка» [20].

${ }^{26}$ Программы «Архитектура и градостроительство» Эстонской Академии Искусств (https://www.artun.ee/erialad/arhitektuur-ja-linnaplaneerimine/ eriala/ulevaade/).
} 
ных научных направлений. Так, на Инженерном факультете Таллиннского технического университета (TalTech) создана Академия архитектуры и урбанистики ${ }^{27}$, где уделяется специализированное внимание градостроительному направлению ${ }^{28}$. При этом дискуссии об избыточном количестве архитекторов [18] сопровождаются переориентацией образования на европейский рынок труда.

Литовская Республика. Несмотря на то, что программы «Архитектура» в Вильнюсской академии искусств и Каунасском технологическом университете предполагают получение умений «визуализировать инновационные архитектурные решения и решения городского планирования, генерировать творческие идеи и воплощать их в жизнь» ${ }^{29}$, они также включают обучение ГИС-технологиям, градостроительству и пространственному планированию, что говорит о широком представлении градостроительства внутри архитектурных программ. Профессиональный дискурс о градостроительстве сосредоточен на поиске решений, в том числе локальных, малобюджетных ${ }^{30}$, для оптимизации планировочных процессов. Отметим, что литовское профессиональное сообщество оценивает социалистический этап истории в резко негативном ключе [19], подчеркивая общую установку на работу по исключению «социалистического» контекста из профессиональной культуры, пространства городов, необходимость кардинальной трансформации территориальных объектов с целью возращениям им идентичных культурных характеристик.

Латвийская Республика. Формально в классификаторе профессий «градостроители и планировщики дорожного движения» принадлежат к группе «Архитекторы, проектировщики, геодезические и картографические инженеры, геодезисты и дизайнеры». Но выделено 9 (!) самостоятельных специализаций, включая «пространственного планировщика», «специалиста по организации движения», «инженера пространственного развития» ${ }^{31}$.

Рига - один из наиболее оснащённых в плане образования из рассматриваемых нами городов. Профессиональное планировочное образование можно получить: в частной «Высшей школе бизнеса, искусств и технологий (RISEBA) ${ }^{32}$
- «архитектор», в Рижском техническом университете (RTU) - «архитектор», и Латвийском сельскохозяйственном университете (LLU) $)^{33}$ - «ландшафтный архитектор». Эти программы дают квалификацию «архитектор», но общая политика их развития включает в себя передачу специфических форм градостроительного мышления: «общественная составляющая профессии особенно характерна для архитекторовпланировщиков, которые являются модераторами между различными слоями общества» [20]. LLU реализует политику «открытого университета» - учебные курсы открыты для прослушивания без поступления в Университет, дополнительно университет развивает Булдурскую садоводческую школу (до-профессиональное среднее образование, в том числе в области «ландшафтной архитектуры»). Наибольшее число научных публикаций связано с развитием системы информирования, просвещения, включения жителей в диалог по вопросам городского развития ${ }^{34}$.

Приведенная мозаика данных позволяет выделить нечто общее в развёртываемых градостроительных сценариях. Бинарные отношения между постсоветским пространством и условным «всем остальным миром» в прошлом: традиционный оценочный тон (успели наверстать упущенное? соответствуете мировым стандартам?) должен смениться пониманием, что перед нами яркое разнообразие моделей и типов градостроительства. Эта многовариантность - отказ от культа градостроительства-как-системы. Принимая действительность во всех ее неопределенности, профессиональные сообщества на постсоветском пространстве (интуитивно? вынужденно? осмысленно?) предпочитают сегодня градостроительство-как-инфраструктуру: гибкие, разветвленные, многоуровневые сети, объединяющие образование, подготовку, совместные диалоги и коммуникации. Они не предполагают стандарта «правильного» устройства и гораздо более сориентированы на трансформации, нежели на рост.

\section{Лumepamypa}

1. Антропологическое понимание города и методология урбанистического изучения [Электронный ресурс] / Ю.П. Ша-

\footnotetext{
${ }^{27}$ Имеется в виду именно «урбанистика» (эстонск. - Arhitektuuri ja urbanistika akadeemia).

28 «Работа в студиях градостроительных проектов, поддерживается... изучением тенденций городского развития 21 века, городской ... социологией, строительным правом, экологической политикой».

${ }^{29}$ См. подробнее https://apply.ktu.edu/courses/course/50-msc-architecture.

${ }^{30}$ Так, исследование «Реальность и перспективы партисипатизации в градостроительных процессах» (в оригинале - «Reality and Perspectives of Public Participation in Urban Planning and Design Processes») было сосредоточено на поиске эффективных «второстепенных действий в процессах городского планирования и проектирования» (в оригинале - «marginal activities in urban planning and design processes»), что представляет собой пример яркого, нетрадиционного ультра-современного подхода к целеполаганию.

${ }^{31}$ Для Латвии градостроитель и инженер по транспорту фактически синонимы с точки зрения стандартов профессиональной деятельности, подробнее (https://m.likumi.lv/doc.php?id=291004).

32 Частная «Высшая школа бизнеса, искусств и технологий» (RISEBA) предлагает программы по архитектуре; учебное заведение ориентировано на медиа-технологии, обучение ведётся на английском языке.

${ }^{33}$ Рижский Технический Университет и Латвийский сельскохозяйственный Университет, программа «Ландшафтная архитектура и планировка» (Аіпаvи arhitektūra un plānošana).

34 Так, Управление развития Риги (см. https://www.rdpad.lv/en/development-strategy/) предоставляет доступ к планам развития, застройки, благоустройства города, инициирует обсуждения, в том числе в режиме онлайн.
} 
баев, А.П. Садохин, О.В. Лабунова, Н.Н. Сазонова // Мониторинг общественного мнения: экономические и социальные перемены. - 2018. - № 3 (145). - С. 248-267. - Режим доступа: https:// elibrary.ru/item.asp?id=35235550 (дата обращения 20.08.2021).

2. Fabula, S. Socialist and Post-socialist Urbanisms: Critical Reflections from a Global Perspective [Электронный ресурс]/, L.B.W. Drummond, D. Young (eds.) // Hungarian Geographical Bulletin. 2020. - № 69 (3). -P. 325-327. - Режим доступа: https://ojs.mtak.hu/index.php/hungeobull/article/view/4247 (дата обращения 18.08.2021). DOI: https://doi.org/10.15201/ hungeobull.69.3.8.

3. Čolić, N. Beyond formality: A contribution towards revising the participatory planning practice in Serbia [Электронный ресурс] / N. Čolić, 0. Dželebdžić // Вебсайт «ResearchGate». - Режим доступа: https://www.researchgate. net/publication/327934005_Beyond_formality_A_ contribution_towards_revising_the_participatory_planning practice_in_Serbia (дата обращения 20.08.2021).

4. Жеблиенок, Н.Н. Градостроительство XXI века будет таким, каким будут градостроители / Н.Н. Жеблиенок // Архитектурный Петербург. - 2019. - № 4 (59). - С. 71-73.

5. Жеблиенок, Н.Н. Градостроительные перспективы: профессиональная подготовка и система знаний / Н.Н. Жеблиенок // Архитектура и строительство России. - 2019. - № 2 (230). - С. 18-25.

6. Жеблиенок, Н.Н. Градостроители разных стран мира: сравниваем, чтобы понять [Электронный ресурс] / Н.Н. Жеблиенок // Материалы блога «Градотомия». - Режим доступа: https://www.gradotomia.com/post/comparing-urbanplanning-education-systems-1 (дата обращения 22.08.2021).

7. Ilchenko, M. Editorial: In Search of the Post-Socialist Urban Geography. How Do We See the Post-Socialist City Today? [Электронный ресурс] / Ilchenko M., Dushkova D. // Вебсайт «ResearchGate». - Режим доступа: https://www.researchgate. net/publication/332901845_Editorial_In_search_of_the_postsocialist_urban_geography_How_do_we_see_the_postsocialist_city_today (дата обращения 18.08.2021).

8. Hirt, S. (2009) Twenty Years of Transition: The Evolution of Urban Planning in Eastern Europe and the Former Soviet Union, 1989-2009 [Электронный ресурс] / S. Hirt, K Stanilov // UNHABITAT. Human Settlements Global Dialogue Series. - Режим доступа: https://unhabitat.org/sites/default/files/downloadmanager-files/Twenty $\% 20$ Years $\% 20$ of $\% 20$ Transition $\% 20$ The $\% 20$ Evolution $\% 20$ of $\% 20$ Urban $\% 20$ Planning $\% 20$ in $\% 20$ Eastern\%20Europe\%20and\%20the\%20Former\%20Soviet $\% 20$ Union\%2C\%201989-2009.pdf (дата обращения 16.08.2021).

9. Шестернёва, Н.Н. Международный опыт образовательной деятельности в области инженерных наук и градостроительства [Электронный ресурс] / Н.Н. Шестернёва // Architecture and Modern Information Technologies (AMIT). - 2014. - № 4 (29). - Режим доступа: https://marhi.ru/ AMIT/2014/4kvart14/shesterneva/shesterneva.pdf (дата обращения: 15.07.2021).
10. Владимиров, В.В. Градостроительство как система научных знаний : Научная монография / В.В. Владимиров, Т.Ф. Саваренская, И.М. Смоляр; под ред. И.М. Смоляра. - М. : УРCC, 1999. - 120 с. ISBN 5-88417-180-3.

11. Maruna, M. Remodelling urban planning education for sustainable development: the case of Serbia градостроительства [Электронный ресурс] / M. Maruna, Rodic D. Milovanovic, R. Colic // International Journal of Sustainability in Higher Education. - 2018. - Vol. 19. - № 4, - pp. 658-680. - Peжим доступа: https://www.emerald.com/insight/content/ doi/10.1108/IJSHE-07-2017-0102/full/pdf?title=remodellingurban-planning-education-for-sustainable-development-thecase-of-serbia. (дата обращения 20.08.2021). DOI: https:// doi.org/10.1108/IJSHE-07-2017-0102/.

12. Panchenko, T. Experience of practices of urban territorial Planning of Belarus [Электронный ресурс] / T. Panchenko // Вебсайт «ResearchGate». - Режим доступа: https://www. researchgate.net/publication/347183925_Experience_of_ practices_of_urban_territorial_Planning_of_Belarus (дата обращения 22.08.2021) DOI: 10.1051/e3sconf/202021202012.

13. Korshunova, N.N. Sustainable Mobility in the Context of Humanization of the Urban Environment: a regional experience / N.N. Korshunova, E.B. Morozova and O.E. Dolinina // IOP Conference «Innovative Technology in Architecture and Design» (ITAD 2020). Series: Materials Science and Engineering. 21-22 May, 2020. - Kharkiv, Ukraine, 2020. - Vol. 907.

14. Потаев Г.А. Градостроительство в Республике Беларусь в XXI веке: ориентиры развития / Г.А. Потаев // Academia. Архитектура и строительство. - 2021. - № 2. - С. 29-35. DOI: 10.22337/2077-9038-2021-2-29-35.

15. Архитекторы отправили мэру Кишинёва письмо с советами по урбанистике [Электронный ресурс] // Вебсайт «Made by Locals» - Режим доступа: https://locals.md/2016/ arhitektoryi-otpravili-meru-kishineva-pismo-s-sovetami-pourbanistike/ (дата обращения 19.08.2021).

16. Молодые урбанисты и их общественные инициативы в Кишинёве [Электронный ресурс] // Вебсайт «Made by Locals» - Режим доступа: https://locals.md/2018/instagramdnya-chisinau_urban-molodoy-urbanist-o-plyusah-i-minusahkishinyova/ (дата обращения 19.08.2021).

17. $0 б$ архитектурном факультете Национального университета архитектуры и строительства Армении [Электронный ресурс] // Национальный университет архитектуры и строительства Армении. Официальный сайт. - Режим доступа: https://nuaca.am/archives/specialties/архитектура?lang=ru (дата обращения 22.08.2021).

18. Люцкевич, Л. Вузы Эстонии выпускают слишком много архитекторов, инженеров не хватает (29.04.2019) [Электронный ресурс] / Л. Люцкевич // ERR.EE. - Режим доступа: https:// rus.err.ee/934797/vuzy-jestonii-vypuskajut-slishkom-mnogoarhitektorov-inzhenerov-ne-hvataet (дата обращения 23.08.2021).

19. Samalavicius, A.L. Facing Globalization: Lithuanian Urbanism between Postcommunism and Postmodernity 
[Электронный ресурс] / A.L. Samalavicius // Вебсайт «ResearchGate». - Режим доступа: https://www.researchgate. net/publication/333263336_Facing_Globalization_Lithuanian_ Urbanism_between_Postcommunism_and_Postmodernity (дата обращения 18.08.2021)

20. Осинская, И. Учим даже на английском: известный архитектор о престижной профессии в Риге [Электронный ресурс] / И. Осинская // Press. - Режим доступа: https://press.lv/post/uchim-dazhe-na-anglijskomizvestnyj-arhitektor-o-prestizhnoj-professii-kotoruyumozhno-poluchit-v-rige (дата обращения 21.08.2021).

\section{References}

1. Shabaev Yu.P., Sadokhin A.P., Labunova O.V., Sazonova N.N. Antropologicheskoe ponimanie goroda i metodologiya urbanisticheskogo izucheniya [Anthropological understanding of the city and the methodology of urban studies]. In: Monitoring obshchestvennogo mneniya: ekonomicheskie i sotsial'nye peremeny [Monitoring public opinion: economic and social changes], 2018, no. 3 (145), pp. 248-267. Access mode: https://elibrary.ru/item.asp?id=35235550 (Accessed 08/20/2021). (In Russ., abstr.in Engl.)

2. Fabula S. Socialist and Post-socialist Urbanisms: Critical Reflections from a Global Perspective [Socialist and Post-socialist Urbanisms: Critical Reflections from a Global Perspective], L.B.W. Drummond, D. Young (eds.). In: Hungarian Geographical Bulletin, 2020, no. 69 (3), pp. 325-327. Access mode: https://ojs.mtak.hu/index.php/hungeobull/ article/view/4247 (Accessed 08/18/2021). D0I: https://doi. org/10.15201/hungeobull.69.3.8. (In Engl.)

3. Čolić N., Dželebdžić 0 . Beyond formality: A contribution towards revising the participatory planning practice in Serbia. «ResearchGate» Websait. Access mode: https:// www.researchgate.net/publication/327934005_Beyond_ formality_A_contribution_towards_revising_the_ participatory_planning_practice_in_Serbia (Accessed 08/20/2021). (In Engl.)

4. Zheblienok N.N. Gradostroitel'stvo XXI veka budet takim, kakim budut gradostroiteli [Urban planning of the XXI century will be the same as urban planners will be]. In: Arkhitekturnyi Peterburg [Architectural Petersburg], 2019, no. 4 (59), pp. 71-73. (In Russ.)

5. Zheblienok N.N. Gradostroitel'nye perspektivy: professional'naya podgotovka i sistema znanii [Urban planning perspectives: professional training and knowledge system]. In: Arkhitektura i stroitel'stvo Rossii [Architecture and Construction of Russia], 2019, no. 2 (230), pp. 18-25. (In Russ., abstr.in Engl.)

6. Zheblienok N.N. Gradostroiteli raznykh stran mira: sravnivaem, chtoby ponyat' [Town planners from different countries of the world: we compare to understand]. In: Materialy bloga «Gradotomiya» [Materials of the blog "Gradotomy"]. Access mode: https://www.gradotomia.com/post/comparingurban-planning-education-systems-1 (Accessed 08/22/2021). (In Russ.)
7. Ilchenko M., D. Dushkova. Editorial: In Search of the PostSocialist Urban Geography. How Do We See the Post-Socialist City Today? ResearchGate website. Access mode: https://www. researchgate.net/publication/332901845_Editorial_In_search_ of_the_post-socialist_urban_geography_How_do_we_see_the post-socialist_city_today (Accessed 08/18/2021). (In Engl.)

8. Hirt S., Stanilov K. Twenty Years of Transition: The Evolution of Urban Planning in Eastern Europe and the Former Soviet Union, 1989-2009. UN-HABITAT, Human Settlements Global Dialogue Series. Access mode: https://unhabitat. org/sites/default/files/download-manager-files/Twenty $\% 20$ Years $\% 20$ of $\% 20$ Transition $\% 20$ The $\% 20$ Evolution $\% 20$ of $\% 20$ Urban\%20Planning\%20in\%20Eastern\%20Europe\%20and\%20 the $\% 20$ Former\%20Soviet $\% 20$ Union $\% 2 C \% 201989-2009$.pdf (Accessed 08/16/2021). (In Engl.)

9. Shesterneva N.N. Mezhdunarodnyi opyt obrazovatel'noi deyatel'nosti v oblasti inzhenernykh nauk i gradostroitel'stva [International experience of educational activities in the field of engineering sciences and urban planning]. In: Architecture and Modern Information Technologies (AMIT), 2014, no. 4 (29). Access mode: https://marhi.ru/AMIT/2014/4kvart14/ shesterneva/shesterneva.pdf (data obrashcheniya: 07/15/2021). (In Russ., abstr.in Engl.)

10. Vladimirov V.V. Savarenskaya T.F., Smolyar I.M. Gradostroitel'stvo kak sistema nauchnykh znanii [Urban planning as a system of scientific knowledge], I.M. Smolyar (ed.). Moscow, URSS, 1999, 120 p. ISBN 5-88417-180-3. (In Russ.)

11. Maruna M. Milovanovic, Rodic D., Colic R. Remodelling urban planning education for sustainable development: the case of Serbia. In: International Journal of Sustainability in Higher Education, 2018, Vol. 19, no. 4, pp. 658-680. Access mode: https://www.emerald.com/insight/content/doi/10.1108/ IJSHE-07-2017-0102/full/pdf?title=remodelling-urbanplanning-education-for-sustainable-development-the-case-ofserbia. (Accessed 08/20/2021). DOI: https://doi.org/10.1108/ IJSHE-07-2017-0102/. (In Engl.)

12. Panchenko T. Experience of practices of urban territorial Planning of Belarus. ResearchGate website. Access mode: https:// www.researchgate.net/publication/347183925_Experience_of_ practices_of_urban_territorial_Planning_of_Belarus (Accessed 08/22/2021) DOI: 10.1051/e3sconf/202021202012. (In Engl.)

13. Korshunova N.N., Morozova E.B., Dolinina O.E. Sustainable Mobility in the Context of Humanization of the Urban Environment: a regional experience. In: IOP Conference «Innovative Technology in Architecture and Design» (ITAD 2020). Series: Materials Science and Engineering. 21-22 May, 2020. Kharkiv, Ukraine, 2020, Vol. 907. (In Engl.)

14. Potaev G.A. Gradostroitel'stvo v Respublike Belarus' v XXI veke: orientiry razvitiya [Urban Planning in the Republic of Belarus in the 21st Century: Development Points]. In: Academia. Arkhitektura i stroitel'stvo [Academia. Architecture and construction], 2021, no. 2, pp. 29-35. DOI: 10.22337/20779038-2021-2-29-35. (In Russ., abstr.in Engl.) 
15. Arkhitektory otpravili meru Kishineva pis'mo s sovetami po urbanistike [Architects sent aletter to the Mayor of Chisinau with advice on urbanism]. Vebsait «Made by Locals» [Website "Made by Locals"]. Access mode: https://locals.md/2016/ arhitektoryi-otpravili-meru-kishineva-pismo-s-sovetami-pourbanistike/ (Accessed 08/19/2021). (In Russ.)

16. Molodye urbanisty $\mathrm{i}$ ikh obshchestvennye initsiativy $\checkmark$ Kishineve [oung urbanists and their public initiatives in Chisinau]. Vebsait «Made by Locals» [Website "Made by Locals"]. Access mode: https://locals.md/2018/instagramdnya-chisinau_urban-molodoy-urbanist-o-plyusah-i-minusahkishinyova/ (Accessed 08/19/2021). (In Russ.)

17. $0 \mathrm{~b}$ arkhitekturnom fakul'tete Natsional'nogo Universiteta arkhitektury i stroitel'stva Armenii [About the Faculty of Architecture of the National University of Architecture and Construction of Armenia]. Natsional'nyi universitet arkhitektury $i$ stroitel'stva Armenii. Ofitsial'nyi sait [National University of Architecture and Construction of Armenia. Official site]. Access mode: https://nuaca.am/archives/specialties/ arkhitektura?lang=ru (Accessed 08/22/2021). (In Russ.)
18. Lyutskevich L. Vuzy Estonii vypuskayut slishkom mnogo arkhitektorov, inzhenerov ne khvataet (29.04.2019) [Estonian universities graduate too many architects, there are not enough engineers (29.04.2019)]. ERR.EE. Access mode: https://rus. err.ee/934797/vuzy-jestonii-vypuskajut-slishkom-mnogoarhitektorov-inzhenerov-ne-hvataet (Accessed 08/23/2021). (In Russ.)

19. Samalavicius A.L. Facing Globalization: Lithuanian Urbanism between Postcommunism and Postmodernity. ResearchGate Website. Access mode: https://www.researchgate. net/publication/333263336_Facing_Globalization_Lithuanian_ Urbanism_between_Postcommunism_and_Postmodernity (Accessed 08/18/2021) (In Engl.)

20. Osinskaya I. Uchim dazhe na angliiskom: izvestnyi arkhitektor o prestizhnoi professii v Rige [We teach even in English: a famous architect about a prestigious profession in Riga]. Press. Access mode: https://press.lv/post/uchim-dazhe-na-anglijskomizvestnyj-arhitektor-o-prestizhnoj-professii-kotoruyumozhno-poluchit-v-rige (Accessed 08/21/2021). (In Russ.)

Жеблиенок Наталья Николаевна (Санкт-Петербург). Кандидат архитектуры, доцент, советник РААСН. Главный градостроитель проектов 000 «Лаборатории градопланирования им. М.Л. Петровича» (190013, Санкт-Петербург, наб. реки Фонтанки, 108, б/ц «Фонтанка 108», офис 1). Эл. почта: shesternevann@gmail.com.

Zheblienok Natalya N. (St. Petersburg). Candidate of Architecture, Associate Professor, Advisor of RAACS. Chief Urban Planner of Projects at the M.L. Petrovich Laboratory of Urban Planning (108 Fontanka river emb., office 1, Saint Petersburg, 190013. Laboratory of Urban Planning).E-mail: shesternevann@gmail.com. 